\title{
HUBUNGAN KESIAPAN BELAJAR MANDIRI DENGAN TINGKAT KECEMASAN PADA MAHASISWA TAHUN PERTAMA FAKULTAS KEDOKTERAN UNIVERSITAS MALAHAYATI TAHUN 2017
}

\author{
Dewi Lutfianawati ${ }^{1}$, Sri Maria Puji Lestari ${ }^{2}$, Septa Istiana ${ }^{2}$ \\ ${ }^{1}$ Prodi Psikologi, Fakultas Kedokteran, Universitas Malahayati \\ ${ }^{2}$ Prodi Pendidikan Dokter, Fakultas Kedokteran, Universitas Malahayati
}

ABSTRAK

Latar belakang: Sistem pembelajaran dengan menggunakan PBL akan memicu munculnya kecemasan. Kecemasan merupakan reaksi kejiwaan yang muncul akibat adanya permasalahan, seperti memandang diri rendah, sulit untuk merasa senang atau pemurung, tidak ada kepercayaan diri, mudah tegang dan gelisah. Faktor pemicu kecemasan salah satunya adalah kurangnya kesiapan belajar mandiri, Pendekatan PBL, diharapkan dapat mendorong mahasiswa mempunyai inisiatif untuk belajar secara mandiri. Kesiapan belajar mandiri merupakan kesiapan atau kesediaan seseorang untuk belajar mandiri, yang terdiri dari komponen sikap, kemampuan dan karakteristik personal. Tujuan Penelitian : Untuk mengetahui hubungan kesiapan belajar mandiri dengan tingkat kecemasan pada mahasiswa tingkat pertama Fakultas Kedokteran Universitas Malahayati Tahun 2017. Metode Penelitian : Jenis penelitian kuantitatif dengan design penelitian analitik dan pendekatan cross sectional. Teknik pengambilan sampel menggunakan metode purposive sampling, data penelitian diperoleh menggunakan kuesioner SDLR dan kuesioner HARS. Uji statistik yang digunakan yaitu uji Somers'd. Hasil : Distribusi frekuensi dari 198 responden di dapatkan bahwa tingkat kesiapan belajar mandiri mahasiswa memiliki kategori tinggi 180 responden $(90,9 \%)$, sedang 13 responden $(6,6 \%)$, dan rendah 5 responden $(2,5 \%)$. Tingkat kecemasan mahasiswa didapatkan kategori tidak ada kecemasan sebanyak 36 responden $(18,2 \%)$, tingkat kecemasan ringan 110 responden $(55.6 \%)$, tingkat kecemasan sedang 48 responden $(24,2 \%)$, dan tingkat kecemasan berat sebanyak 4 responden $(2,0 \%)$. Hasil uji statistic somers'd diperoleh nilai $P$ value sebesar $0.217(p<0.05)$ Kesimpulan : Tidak terdapat hubungan yang signifikan antara kesiapan belajar mandiri dengan tingkat kecemasan pada mahasiswa Kedokteran Malahayati Angkatan 2017 di Universitas Malahayati.

Kata Kunci: tingkat kecemasan, Kesiapan Belajar Mandiri

\section{PENDAHULUAN}

Latar Belakang Menurut White\& Watt, 1981 (dalam Maulana $\mathrm{H}$ et al, 2014) menyatakan bahwa Kecemasan merupakan suatu kondisi yang pernah dialami oleh hampir semua individu, hanya saja kadar dan tarafnya yang berbeda. Ada individu yang dapat menyelesaikan masalah-masalahnya hingga kecemasan yang dialami tidak berkepanjangan, tetapi tidak jarang kecemasan tersebut mendatangkan gangguan bagi yang mengalaminya
Kecemasan dapat didefinisikan sebagai kondisi emosional yang tidak menyenangkan, yang ditandai oleh perasaan-perasaan subyektif seperti ketegangan, ketakutan, kekhawatiran dan juga ditandai dengan aktifnya sistem syaraf pusat. (Mu'arifah, 2005) Kecemasan merupakan reaksi kejiwaan yang muncul akibat adanya permasalahan, seperti memandang diri rendah, sulit untuk merasa senang atau pemurung, tidak ada kepercayaan diri, mudah tegang dan gelisah. Hal ini dapat 
terjadi karena kurangnya arahan dalam belajar, tidak efektifnya sistem pembelajaran dan informasi yang kurang akurat, kelompok diskusi yang kurang dinamis dan tidak terdapat sikap saling membantu antar peserta menjadi pemicu dalam timbulnya kecemasan (Bakhriansyah, 2012). Penelitian yang di lakukan oleh Triastuti (2013), di Fakultas Kedokteran Muhammdiyah Surakarta dengan tema hubungan Self Directed Learning Readiness dengan tingkat kecemasan mahasiswa tingkat pertama fakultas kedokteran Universitas Muhammdiyah Surakarta, menunjukkan bahwa nilai Sig dari kecemasan jiwa adalah 0,550, kecemasan fisika 0,260 dan kecemasan umum 0,079, nilai ini menunjukkan bahwa tidak ada hubungan yang signifikan antara kesiapan belajar mandiri dan tingkat kecemasan. Berdasarkan hasil penelitian, dapat disimpulkan bahwa kesiapan belajar mandiri tidak memiliki hubungan yang signifikan dengan tingkat kecemasan pada mahasiswa pendidikan kedokteran pertama Universitas Muhammadiyah Surakarta. Penelitian juga di lakukan oleh Subhakti (2017), di Fakultas Kedokteran Universitas Malahayati, menjelaskan bahwa tingkat kecemasan mahasiswa peserta OSCE lebih tinggi dengan kecemasan berat $64(56 \%)$ sedangkan tingkat kecemasan peserta CBT lebih rendah dengan kecemasan ringan 58 (51\%). Lalu Penelitian di lakukan oleh Riga (2016) nilai rata-rata tingkat kecemasan adalah 21,75 $\pm 4,82 \%$.

Berdasarkan hasil wawancara yang dilakukan sebagai presurvey pada hari Jum'at tanggal 15 Desember 2017 pada 10 orang mahasiswa angkatan 2017 diperoleh data bahwa kesiapan belajar mandiri pada mahasiswa tingkat pertama belum baik, dimana mahasiswa belum memiliki pemahaman akan kesiapan belajar mandiri sehingga membuat mahasiswa tingkat pertama memiliki sikap merasa cemas. Wawancara dilakukan dari kamar ke kamar dan di lokasi praktikum diambil dari 10 orang, pria 6 orang dan wanita 4 orang. Hasil wawancara tersebut didapatkan bahwa $20 \%$ mahasiswa/i tidak memiliki sikap cemas dan $80 \%$ mahasiswa/i memiliki sikap cemas seperti jantung berdebar, keringat dingin, bahkan ada yang memiliki rasa ingin buang air besar karena belum memiliki kesiapan belajar mandiri dengan baik. Berdasarkan presurvey didapatkan bahwa mahasiswa Program Studi Kedokteran Universitas Malahayati masih belum memiliki kesiapan belajar mandiri sehingga mengakibatkan mahasiswa memiliki sikap cemas. Perubahan paradigma pendidikan kedokteran, menyebabkan perlu diadakan perubahan pada kurikulum pendidikan dokter khususnya kedokteran dasar di Indonesia, dari sistem konvensional berupa teacher centered learning menjadi kurikulum berbasis kompetensi (KBK) dengan metode student centered learning (SCL). KBK bisa dilaksanakan dengan berbagai cara, salah satunya dengan pendekatan Problem Based Learning ( $P B L$ ) (KKI, 2012).

Pendekatan PBL menggunakan masalah-masalah dalam kehidupan nyata yang digunakan untuk menstimulasi rasa keingintahuan serta kemampuan analisis mahasiswa terhadap materi pembelajaran (Pioh et al., 2016). Keterlibatan mahasiswa pada suatu pemecahan masalah bemaksud agar mereka dapat menyusun pengetahuan mereka sendiri dari hasil pemecahan masalah yang ditemukannya. Proses tersebut mendorong mahasiswa lebih mandiri mengembangkan cara berfikir dan kemampuan memecahkan masalah yang mereka temukan sendiri. Masalahmasalah tersebut sebagai fokus belajar pada pendekatan PBL sehingga mahasiswa mampu berfikir kritis dalam memecahkan masalah (Pioh et al., 2016). Pendekatan PBL, diharapkan dapat mendorong mahasiswa mempunyai inisiatif untuk belajar secara mandiri, yang 
dikenal sebagai self directed learning (SDL) (Hallock, 2009). Proses dalam SDL ini dilakukan dengan menyadari kebutuhan sendiri dalam belajar, mengatur tujuan pribadi, membuat keputusan atas sumber dan strategi belajar dan menilai hasil dari apa yang telah dilakukan (Ambarsarie, 2016). Salah satu prediktor penting untuk memperkirakan keberhasilan mahasiswa dalam lingkungan belajar yang menuntut kemandirian adalah dengan memahami kesiapan belajar mandiri/self-directed learning readiness (SDLR). SDLR merupakan kesiapan atau kesediaan seseorang untuk belajar mandiri, yang terdiri dari komponen sikap, kemampuan dan karakteristik personal. Apabila dikaitkan dengan hukum law of readiness dari Thorndike dapat diambil pengertian bahwa bila seseorang mahasiswa dihadapkan dengan stimulus berupa lingkungan belajar yang menuntut kemandirian dan keaktifan, maka dibutuhkan kesiapan mahasiswa tersebut untuk merespon stimulus tersebut sehingga nantinya proses belajar menjadi lancar dan dapat meraih prestasi belajar yang memuaskan (Ambarsarie, 2016). Berdasarkan penelitian yang di lakukan di Universitas Lampung Fakultas Kedokteran diketahui bahwa Terdapat 169 (74,8\%) orang memiliki SDLR tinggi, 57 (25,2\%) orang memiliki SDLR sedang, dan tidak ada responden yang memiliki SDLR rendah (Sumbayak, 2017). Kemudian, Penelitian yang dilakukan di Universitas Malahayati Fakultas Kedokteran diketahui bahwa SDLR baik 75,2\%, dan SDLR kurang baik 24,8\%. (Kusuma, 2016) Belajar mandiri adalah suatu proses dimana individu berinisiatif dengan ataupun tanpa bantuan orang lain, untuk menentukan kebutuhan belajar, merumuskan tujuan belajar, mengidentifikasi sumber daya untuk belajar. Proses belajar mendiri menunjukan tingkat kesadaran dan tanggung jawab mahasiswa yang lebih besar terhadap kegiatan pembelajar dan hasil belajar yang dicapai. Belajar mandiri melihat suatu masalah sebagai tantangan yang mengharuskan mahasiswa untuk mandiri, disiplin, percaya diri, dan berorientasi pada tujuan, dengan sikap demikian akan membuat proses belajar semakin mudah dan menyenangkan (Shaikh, 2013).

\section{Metode Penelitian}

Metode Penelitian Jenis penelitian kuantitatif dengan design penelitian analitik dan pendekatan cross sectional. Teknik pengambilan sampel menggunakan metode purposive sampling, data penelitian diperoleh menggunakan kuesioner SDLR dan kuesioner HARS. Uji statistik yang digunakan yaitu uji Somers'd

Kriteria Inklusi

1. Mahasiswa Kedokteran Umum Universitas Malahayati Angkatan 2017

2. Mahasiswa yang hadir pada saat pembagian kuesioner.

3. Mahasiswa yang bersedia mengisi kuesioner dan mengumpulkan kuesioner. Kriteria Eklusi

1. Mahasiswa yang sakit

2. Mahasiswa yang sedang dalam perawatan psikiater

\section{HASIL}

Analisis Univariat

Distribusi Frekuensi kesiapan belajar mandiri Mahasiswa Angkatan 2017 Fakultas Kedokteran Universitas Malahayati Kesiapan Belajar Mandiri Frekuensi Persentase (\%) Rendah 5 2,5 Sedang 13 6,6 Tinggi 180 90,9 Total 198 100 jenis_kelamin Frekuensi Persentase (\%) laki-laki $67 \quad 33,8$ Perempuan 131 66,2 Total 198100.

Mahasiswa angkatan 2017 Fakultas Kedokteran Universitas Malahayati tahun 2018, sebagian besar memiliki kesiapan belajar mandiri tinggi sebanyak 180 responden $(90,9 \%)$. 
Persepsi mahasiswa terhadap indikator kesiapan belajar mandiri/SDLR. Dimensi SDLR diukur melalui 3 indikator yaitu manajemen diri, keinginan untuk belajar, karakteristik pengendalian diri, dengan ratarata mean dari seluruh indikator adalah 3,94. Setiap indikator dalam SDLR dinyatakan baik jika nilai mean $\geq 3,94$, dan dinyatakan kurang baik jika nilai mean $<3,94$. Indikator yang termasuk ke dalam kategori baik yaitu mengatur tujuan belajar saya sendiri, mengevaluasi kinerja saya sendiri, bertanggung jawab, mempertahankan Indeks Prestasi Kumulatif (IPK) dalam keadaan bagus dan memuaskan, mau belajar mengenai informasi baru, mampu mengarahkan metode pembelajaran, memprioritaskan tugas saya, perlu tahu mengapa sesuatu terjadi, harus mengendalikan apa yang saya pelajari, bertanggung jawab, terbuka untuk kesempatan belajar baru, mengendalikan kegiatan saya sehari-hari, menikmati belajar tentang informasi baru, percaya bahwa peran seorang guru ialah sebagai narasumber, mengatur kriteria dalam mengevalusi kinerja, menikmati tantangan, Sadar akan kekurangan diri, menikmati proses belajar, dan mengatur waktu saya dengan baik. Indikator dengan nilai tertinggi adalah mau belajar mengenai informasi baru, dengan nilai mean $(4,32)$, sedangkan nilai terendah adalah selalu efektif mengatur belajar saya dengan nilai mean $(3,60)$

Distribusi frekuensi tingkat kecemasan (HARS) Mahasiswa Angkatan 2017 Fakultas Kedokteran Universitas Malahayati Cemas Frekuensi Persentase (\%) tidak ada kecemasan $36 \quad 18.2$ kecemasan ringan 11055.6 kecemasan sedang 4824.2 kecemasan berat 42.0 Total 198 100.0. Berdasarkan tabel 4.5 diketahui bahwa mahasiswa angkatan 2017 Fakultas Kedokteran Universitas Malahayati tahun 2018, sebagian besar memiliki tingkat kecemasan ringan sebanyak 110 responden (55.6\%).

\section{Analisis Bivariat}

Berdasarkan hasil uji statistic somers'd diperoleh nilai $P$ value sebesar 0.217 ( $p \geq$ 0.05 ) yang berarti tidak terdapat hubungan yang signifikan antara kesiapan belajar mandiri dengan tingkat kecemasan pada mahasiswa Kedokteran Umum Angkatan 2017 Di Universitas Malahayati Bandar Lampung.

Hasil penelitian 198 responden diketahui bahwa mahasiswa Pendidikan Sarjana Kedokteran Umum Angkatan 2017 di Universitas Malahayati tahun 2018, memiliki kesiapan belajar mandiri yang tinggi sebanyak 180 responden $(90,9 \%)$, memiliki kesiapan belajar mandiri yang sedang sebanyak 13 resonden $(6,6 \%)$, dan memiliki kesiapan belajar mandiri yang rendah sebanyak 5 responden $(2,5 \%)$. Dapat disimpulkan kesipan belajar mandiri pada mahasiswa angkatan 2017 di Universitas Malahayati sudah cukup baik. Dapat disimpulkan kesipan belajar mandiri pada mahasiswa angkatan 2017 di Universitas Malahayati sudah cukup baik. Mahasiswa yang memiliki kemandirian dalam belajar mereka mempunyai tanggung jawab dalam mengatur dan mendisiplinkan dirinya dan dalam mengembangkan kemampuan belajar atas kemauan diri. Sikapsikap tersebut perlu dimiliki mahasiswa karena hal tersebut ciri kedewasaan orang terpelajar. (Rusman, 2014). Kesiapan belajar mandiri (SDLR) sangatlah penting dalam pendidikan kedokteran untuk memberi bekal menjadi seorang Long Life Learner. Lulusan pendidikan dokter harus memiliki kemampuan sesuai Dengan Standar Kompetensi Dokter Indonesia (SKDI) yang disahkan oleh Konsil Kedokteran Indonesia (KKI). Salah satu kompetensi yang harus dimiliki oleh seorang dokter di Indonesia adalah kompetensi mawas diri dan pengembangan diri. (KKI, 2012) Hasil penelitian dengan kesiapan belajar yang tinggi sejalan dengan teori Sugianto (2016) ia menyatakan bahwa seseorang 
yang berhasil dalam proses pembelajaran SDLR adalah seseorang yang memiliki inisiatif, mandiri, dan gigih dalam belajar. Lebih lanjut mereka bertanggung jawab atas pembelajarannya sendiri, memandang masalah sebagai suatu tantangan, memiliki rasa keingintahuan, dan disiplin. Mereka mampu mengkombinasikan kepercayaan diri dan keinginan yang kuat untuk belajar, mengorganisasi waktu, mengatur kecepatan belajar, memiliki perencanaan, menikmati belajar, dan berorientasi pada tujuan. Hal yang mempengaruhi tingginya SDLR pada mahasiswa angkatan 2017 di Universitas Malahayati, menurut Dolmans dan Schmith (Wijayanto, 2013) kemampuan menerapkan kesiapan belajar mandiri membaik dengan semakin lama menjalani kurikulum PBL selama 3,5 tahun yang menajamkan mahasiswa untuk mampu belajar mandiri, diakhir tahap pendidikan sarjana kedokteran diharapkan mahasiswa telah menjadi lebih mandiri dan siap untuk belajar difase kepanitraan. Pada penelitian Pamungkasari (2012) sebagian besar mahasiswa tahap pendidikan profesi mempunyai kesiapan belajar mandiri yang tinggi. Dari hasil peneltian yang dilakukan didapatkan indikator kesiapan belajar mandiri dengan nilai tertinggi yang dialami mahasiswa Kedokteran Umum Angkatan 2017 adalah: 1. "Mempertahankan Indeks Prestasi Kumulatif (IPK) dalam keadaan bagus dan memuaskan", dengan nilai mean $(4,32)$, 2. "Mau belajar mengenai informasi baru", dengan nilai mean $(4,23), 3$. "Bertanggung jawab", dengan nilai mean $(4,16)$. Sedangkan nilai terendah adalah 1. "Selalu efektif mengatur belajar saya", dengan nilai mean $(3,60)$. 2. "Sistematis dalam belajar", dengan nilai mean $(3,70)$. 3. "Mengatur waktu saya secara ketat", dengan nilai mean $(3,72)$.

Hasil penelitian juga sejalan dengan penelitian yang di lakukan di Universitas Lampung Fakultas Kedokteran diketahui bahwa Terdapat $169 \quad(74,8 \%)$ orang memiliki SDLR tinggi, 57 (25,2\%) orang memiliki SDLR sedang, dan tidak ada responden yang memiliki SDLR rendah (Sumbayak, 2017). Kemudian, Penelitian yang dilakukan oleh Cita Pakarti Dharma Kusuma di Universitas Malahayati Fakultas Kedokteran diketahui bahwa SDLR baik $75,2 \%$, dan SDLR kurang baik 24,8\% (kusuma, 2016). Lalu penelitian yang dilakukan oleh Ahmad Farhan Shadiqin di Universitas Malahayati Fakultas Kedokteran bahwa SDLR tinggi sebanyak 90,9\%, dan SDLR rendah sebanyak 9,9\% (Shadiqin, 2016).

Mahasiswa angkatan 2017 Fakultas Kedokteran Universitas Malahayati tahun 2018, yang memiliki tidak ada kecemasan ada 36 responden $(18,2 \%)$, memiliki tingkat kecemasan ringan sebanyak 110 responden $(55.6 \%)$, memiliki tingkat kecemasan sedang sebanyak 48 responden $(24,2 \%)$, memiliki tingkat kecemasan berat sebanyak 4 responden $(2,0 \%)$. Hasil dari penelitian tentang cemas adalah bahwa mahasiswa tahun pertama memiliki kecemasan ringan, penelitian ini sejalan dengan Coleman bahwa tingkat kecemasan tergantung pada pengalaman- pengalamannya, sehingga mempengaruhi cara individu dalam mengevaluasi keadaan yang menimbulkan kecemasan. Mahasiswa yang memiliki masa studi lebih lama, memiliki pengalaman yang lebih banyak dalam menghadapi masalah dalam perkuliahan sehingga menjadi lebih tahan terhadap tekanan-tekanan yang dialaminya dibandingkan dengan mahasiswa masa studi tahun pertama (Zulkarnain, Novliadi, 2009). Hal-hal yang dapat menyebabkan masalah psikologis ini diantaranya adalah tekanan akademik, belum familiar dengan lingkungan pendidikan yang baru dan ekspektasi yang tidak realistis. Semua penemuan tersebut di atas mengindikasikan bahwa mahasiswa kedokteran tahun pertama sangat rentan untuk mengalami masalah 
psikologis (Daniel, 2012). Kecemasan ringan merupakan kecemasan yang normal dirasakan agar seseorang lebih waspada dan dapat meningkatkan motivasi belajar dan meningkatkan kreatifitas. Manifestasi yang muncul pada tingkat ini adalah kelelahan, iritabel, lapang persepsi meningkat, kesadaran tinggi, mampu untuk belajar, motivasi meningkat, dan tingkah laku sesuai situasi (Hawari, 2011) Kecemasan merupakan reaksi normal terhadap situasi yang menekan kehidupan seseorang, dan karena itu tidak berlangsung lama. Kecemasan merupakan efek lazim dalam mayoritas penyakit psikiatris. Kecemasan merupakan respon fisiologis dan respon psikologis agar individu dapat waspada terhadap hal yang akan terjadi pada dirinya (Ramaiah, 2003). Kecemasan adalah suatu keadaan yang timbul saat gugup berlebihan hal ini dapat menurunkan kinerja pada lingkungan kerja terutama lingkungan pendidikan (Karatas H, Alci B, Aydin H, 2013). Kecemasan muncul karena ada faktor pemicunya, yaitu: Beban kuliah dan meningkatnya kompleksitas materi, ujian, kurangnya kesiapan belajar, dan pikiran irasional mengenai ujian dan hasilnya (Indah, 2017). Penelitian ini tidak sejalan dengan yang di kemukakan Hasianna (2014) bahwa mahasiswa kedokteran memiliki tingkat kecemasan yang tinggi karena peran pentingnya mahasiswa tersebut dalam bidangnya. Pada mahasiswa semester awal diasumsikan bahwa mahasiswa sedang mengalami perubahan lingkungan dari masa SMA ke jenjang kuliah sehingga harus beradaptasi terhadap lingkungan baru Penelitian ini sejalan dengan Penelitian yang di lakukan oleh Triastuti (2013), di Fakultas Kedokteran Muhammdiyah Surakarta dengan tema hubungan Self Directed Learning Readiness dengan tingkat kecemasan mahasiswa tingkat pertama fakultas kedokteran Universitas Muhammdiyah
Surakarta, menunjukkan bahwa nilai Sig dari kecemasan jiwa adalah 0,550, kecemasan fisika 0,260 dan kecemasan umum 0,079. Penelitian juga di lakukan oleh Subhakti (2017), di Fakultas Kedokteran Universitas Malahayati, menjelaskan bahwa tingkat kecemasan mahasiswa peserta OSCE lebih tinggi dengan kecemasan berat 64 (56\%) sedangkan tingkat kecemasan peserta CBT lebih rendah dengan kecemasan ringan 58 (51\%). Hasil penelitian ini tidak sejalan dengan hasil kecemasan peneliti, karena penelitian yang dilakukan oleh Subhakti (2017) subjeknya adalah mahasiswa kedokteran yang telah selesai tahap dokter muda/koas.

Hubungan Kesiapan Belajar Mandiri Dengan Tingkat Kecemasan Pada Mahasiswa Angkatan 2017 Fakultas Kedokteran Universitas Malahayati

Berdasarkan tabel 4.5 diatas responden tertinggi yaitu 180 responden dengan kesiapan belajar mandiri yang tinggi didapatkan yang tidak cemas sebanyak 34 $(18,9 \%)$, cemas ringan $101(56,1 \%)$, cemas sedang $41(22,8 \%)$, cemas berat 4 (2,2\%). Lalu kedua tertinggi yaitu 13 responden dengan kesiapan belajar mandiri yang sedang didapatkan tidak cemas sebanyak $1(7,7 \%)$, cemas ringan $7(53,8 \%)$, cemas sedang $5(38,5 \%)$, cemas berat $0(0 \%)$. Sedangkan jumlah responden terendah yaitu 5 responden dengan kesiapan belajar mandiri yang rendah didapatkan yang tidak cemas sebanyak $1(20 \%)$, cemas ringan 2 $(40 \%)$, cemas sedang $2(40 \%)$, cemas berat 0 (0\%). Berdasarkan hasil uji statistic somers'd diperoleh nilai $P$ value sebesar 0.217 ( $p<0.05$ ) yang berarti tidak terdapat hubungan yang signifikan antara kesiapan belajar mandiri dengan tingkat kecemasan. Hasil penelitian di atas mengindikasikan bahwa kesiapan belajar mandiri dengan tingkat kecemasan tidak ada hubungan pada Mahasiswa Kedokteran Umum Angkatan 2017 di Universitas Malahayati Bandar 
Lampung. Hal tersebut menunjukkan bahwa kesiapan mahasiswa dalam menghadapi praktikkum dan tutorial bukan satu-satunya faktor yang dapat mempengaruhi tingkat kecemasan seseorang namun masih banyak faktor lain yang diduga dapat mempengaruhi tingkat kecemasan mahasiswa. Faktorfaktor lain yang dapat mempengaruhi tingkat kecemasan, misalnya: menurut Ramaiah 2003 (dalam Manu, 2017), ada beberapa faktor yang mempengaruhi reaksi kecemasan, diantaranya. yaitu: a. Faktor Lingkungan yaitu mahasiswa tahun pertama menghadapi masalah-masalah seperti lepas dari keluarga dan teman serta adaptasi dengan lingkungan belajar yang baru yang penuh tuntutan. Selain itu faktor lain yang berperan adalah diseksi cadaver, beban kuliah yang berat dan kekhawatiran terhadap performa akademiknya. Usaha untuk menguasai informasi yang luas dan berada di kelompok yang memiliki motivasi dan tingkat kecerdasan yang sama dapat mengintimidasi mahasiswa. b. Emosi yang ditekan yaitu kecemasan bisa terjadi jika individu tidak mampu menemukan jalan keluar untuk perasaannya sendiri dalam hubungan personal ini, terutama jika dirinya menekan rasa marah atau frustasi dalam jangka waktu yang sangat lama. c. Sebab-sebab fisik yaitu pikiran dan tubuh senantiasa saling berinteraksi dan dapat menyebabkan timbulnya kecemasan. Hal ini terlihat dalam kondisi seperti misalnya kehamilan, semasa remaja dan sewaktu pulih dari suatu penyakit.Selama ditimpa kondisi-kondisi ini, perubahan-perubahan perasaan lazim muncul, dan ini dapat menyebabkan timbulnya kecemasan. Berbagai sumber kecemasan yang dialami mahasiswa Fakultas Kedokteran dapat muncul dari berbagai metode pembelajaran. Sistem pembelajaran dengan menggunakan PBL akan menguatkan munculnya kecemasan karena kurangnya arahan dalam belajar, tidak efektifnya sistem pembelajaran dan informasi yang kurang akurat, kelompok diskusi yang kurang dinamis dan tidak terdapat sikap saling membantu antar peserta juga menjadi pemicu dalam timbulnya kecemasan. (Bakhriansyah, 2012)

Arikunto 1993 (dalam Yanti, 2013) menyatakan kecemasan harus diusahakan menyingkirkannya, atau sekurangkurangnya dapat ditekan menjadi minimal. Mengingat dampak negatifnya, maka perlu ada upayaupaya tertentu untuk mencegah dan mengurangi kecemasan. Upaya upaya tersebut menurut Sudrajat 2008 (dalam Yanti, 2013) diantaranya dapat dilakukan melalui: a. Menciptakan suasana pembelajaran yang menyenangkan, b. Selama kegiatan pembelajaran berlangsung guru seyogyanya dapat mengembangkan sense of humor dirinya maupun para mahasiswanya, c. Memberikan materi dan tugas-tugas akademik dengan tingkat kesulitan yang moderat, artinya tidak terlalu mudah dan tidak terlalu sulit, d. Mengembangkan sistem penilaian yang menyenangkan, dengan memberikan kesempatan kepada mahasiswa untuk melakukan penilaian diri atas tugas dan pekerjaan yang telah dilakukannya, e. Guru seyogyanya berupaya untuk menanamkan kesan positif dalam diri mahasiswa, $f$. Menciptakan lingkungan yang nyaman dan terbebas dari berbagai gangguan, terapkan disiplin sekolah yang manusiawi serta hindari bentuk tindakan kekerasan fisik maupun psikis di lingkungan kampus, baik yang dilakukan oleh dosen, teman maupun orang-orang yang berada di lingkungan perkuliahan. Melalui upayaupaya di atas diharapkan para mahasiswa dapat terhindar dari berbagai bentuk kecemasan dan mereka dapat tumbuh dan dan berkembang menjadi individu yang sehat secara fisik maupun psikis. Lalu hasil penelitian menunjukkan bahwa sebagian besar mahasiswa tahun pertama memiliki cemas ringan, hal ini dapat 
terjadi karena penelitian ini dilakukan pada semester 2 akhir dimana memungkinkan mahasiswa sudah beradaptasi dengan lingkungannya. Menurut penelitian Lylla, seseorang membutuhkan waktu 66 hari untuk beradaptasi dengan lingkungan, semakin komplek permasalahan yang dihadapi, semakin membutuhkan waktu yang lebih (Sandjaja, 2017). Sedangkan hasil yang menunjukkan bahwa mahasiswa tahun pertama memiliki cemas berat, Feryal 2007 (dalam Akbar, 2015) mengatakan sebagian mahasiswa mengalami kecemasan dengan intensitas yang tinggi. Kemudian hal ini sejalan dengan survei oleh Mancevska, mahasiswa kedokteran tahun pertama memiliki tingkat kecemasan yang tinggi. Kecemasan pada mahasiswa tingkat pertama dapat disebabkan oleh beberapa hal, mereka harus beradaptasi dengan lingkungan di perkuliahan yang berbeda dengan kehidupannya di jenjang SMA. Saat ini, pendidikan kedokteran menggunakan sistem kuliah dengan berbasis dari masalah (KBKPBL). Dengan sistem ini, diharapkan mahasiswa berperan aktif dan mandiri dalam belajar. (Sandjaja, 2017). Sedangkan menurut Kirklan menyatakan bahwa tingkat kecemasan yang sedang biasanya mendorong belajar, sedang tingkat kecemasan yang tinggi mengganggu belajar. Jadi disimpulkan bahwa setiap mahasiswa memiliki kadar atau tingkat kecemasan yang berbedabeda (Yanti, 2013). Kecemasan atau anxiety berasal dari Bahasa Latin angustus yang berarti kaku, dan ango, anci yang berarti mencekik. Kecemasan adalah perasaan yang menetap berupa kekuatan (was-was, khawatir atau cemas) yang merupakan respon terhadap ancaman yang akan datang. Kecemasan dianggap berbahaya apabila hal tersebut merupakan perasaan berlebihan yang ditekan kedalam bawah alam sadar, jika terjadi peningkatan akan adanya bahaya (Ibrahim, 2012) Menurut Sugianto (2016)
Self directed learning adalah sebuah proses mental yang ditujukan secara pribadi disertai dan didukung oleh kegiatan perilaku yang terlibat dalam mengidentifikasi dan mencari informasi. Menurut Wiley 1983 (dalam Sumbayak, 2017) kesiapan belajar mandiri (selfdirected learning readiness) didefinisikan sebagai tingkat individu memiliki sikap, kemampuan dan karakteristik yang diperlukan dalam proses belajar mandiri. Definisi menghasilkan beberapa asumsi mengenai kesiapan SDL. Pertama, orang dewasa pada dasarnya memiliki sifat selfdirected, artinya kesiapan dalam melakukan SDL merupakan rangkaian kesatuan dan muncul pada diri individu selama individu tersebut masih ada. Kedua, kompetensi yang dibutuhkan untuk mengarahkan diri dapat dikembangkan sampai batas tertentu dan cara terbaik untuk mempelajari perilaku otonom adalah dengan berperilaku secara mandiri. Ketiga, kemampuan untuk belajar mandiri dalam satu situasi atau konteks dapat digeneralisasi untuk pengaturan lain dalam diri individu Hasil penelitian ini menunjukkan bahwa mahasiswa tahun pertama memiliki kesiapan belajar mandiri yang baik, penelitian ini sejalan dengan teori Guglielmino LM (dalam Sugianto, 2016) Seseorang yang berhasil dalam proses pembelajaran SDLR adalah seseorang yang memiliki inisiatif, mandiri, dan gigih dalam belajar. Lebih lanjut mereka bertanggung jawab atas pembelajarannya sendiri, memandang masalah sebagai suatu tantangan, memiliki rasa keingintahuan, dan disiplin. Mereka mampu mengkombinasikan kepercayaan diri dan keinginan yang kuat untuk belajar, mengorganisasi waktu, mengatur kecepatan belajar, memiliki perencanaan, menikmati belajar, dan berorientasi pada tujuan. Jadi kesiapan belajar mandiri adalah kemampuan mahasiswa mengambil inisiatif untuk bertanggung jawab terhadap pelajarannya dengan atau 
tanpa orang lain yang meliputi aspek: kesadaran, strategi belajar, kegiatan belajar, evaluasi, dan keterampilan interpersonal. Penelitian ini sejalan dengan yang di lakukan oleh Triastuti (2013), di Fakultas Kedokteran Muhammdiyah Surakarta dengan tema hubungan Self Directed Learning Readiness dengan tingkat kecemasan mahasiswa tingkat pertama Fakultas Kedokteran Universitas Muhammdiyah Surakarta, menunjukkan bahwa nilai Sig adalah 0,550, nilai ini menunjukkan bahwa tidak ada hubungan yang signifikan antara kesiapan belajar mandiri dan tingkat kecemasan. Berdasarkan hasil penelitian, dapat disimpulkan bahwa kesiapan belajar mandiri tidak memiliki hubungan yang signifikan dengan tingkat kecemasan pada mahasiswa pendidikan kedokteran pertama Universitas Muhammadiyah Surakarta.

\section{Kesimpulan}

1. Diketahui bahwa dari 198 responden terdapat sebanyak 180 responden $(90,9 \%)$ kategori SDLR tinggi, 13 resonden $(6,6 \%)$ kategori SDLR, dan 5 responden $(2,5 \%)$ kategori SDLR rendah. Dapat disimpulkan kesipan belajar mandiri pada mahasiswa angkatan 2017 di Universitas Malahayati sudah cukup baik 2. Diketahui bahwa dari 198 responden terdapat sebanyak 36 responden $(18,2 \%)$ tidak ada kecemasan, sebanyak 110 responden $(55.6 \%)$ kecemasan ringan, sebanyak 48 responden $(24,2 \%)$ kecemasan sedang, sebanyak 4 responden $(2,0 \%)$ kecemasan berat. 3 . Hasil hubungan kesiapan belajar mandiri dengan tingkat kecemasan yang di analisa dengan uji Somers'd di peroleh nilai pvalue 0,217 ( $p<0.05)$ yang berarti tidak terdapat hubungan yang signifikan antara kesiapan belajar mandiri dengan tingkat kecemasan pada Mahasiswa Kedokteran Umum Angkatan 2017.

Saran
Bagi Institusi Pendidikan 1. Diharapkan institusi dapat meningkatkan dukungan dengan mengoptimalkan peran dosen pembimbing akademik (PA) agar memberikan motivasi kepada mahasiswa untuk mengatur waktu dengan baik dengan menyusun jadwal secara sistematis, sistematis dalam belajar, serta memilih metode pembelajaran sendiri. Bagi Mahasiswa

1. Diharapkan hubungan antar mahasiswa dapat menimbulkan dampak positif (seperti kerja kelompok, belajar bersama, saling memberikan semangat akan giat belajar) sehingga dapat memberikan kesiapan belajar yang baik kemudian mengurangi ketegangan saat belajar. 2 . Mahasiswa yang sudah memiliki kesiapan belajar mandiri yang tinggi dapat bertanggung jawab dalam menyelesaikan tugas yang diberikan secara mandiri dan tepat waktu, mampu membiasakan

padatnya jadwal perkuliahan, serta mampu memprioritaskan kegiatan yang harus diselesaikan terlebih dahulu 3 . Diharapkan mahasiwa dapat lebih mengatur kegiatannya dengan baik, dengan mengisi waktu luangnya dengan hal yang bermanfaat untuk dirinya seperti membaca buku atau berdialog tentang materi blok yang sedang dijalani, tanpa melupakan kegiatan atau ibadahnya dalam agama masing-masing 4. Diharapkan mahasiswa dapat belajar secara sistematis serta meyakini apa yang dipejalarinya tidak akan menjadi sia-sia, dan diharapkan dapat memilih metode belajarnya sendiri, seperti belajar sambil mendengar musik, belajar sambil berdiskusi dengan teman, dan belajar dalam keadaan tenang tanpa ada hal-hal yang mengganggu seperti belajar di malam hari. 5. Diharapkan mahasiswa belajar kembali setelah melakukan skill lab, agar apa yang dipelajari terus diingat dan tidak melupakan apa yang telah di pelajari.

Bagi Peneliti Selanjutnya 
1. Diharapkan hasil penlitian ini dapat menjadi tambahan referensi bagi peneliti selanjutnya dan bahan acuan untuk meneliti tentang faktor lain yang dapat menyebabkan kecemasan, serta kesiapan belajar mandiri. 2. Penelitian yang akan datang baik yang dilaksanakan sendiri maupun penelitian lain diharapkan dalam penyusunan instrumen penelitian lebih spesifik dan memenuhi aspek atau ruang lingkup alat ukur, sehingga dapat lebih terungkap lagi faktor-faktor yang mempengaruhi kesiapan belajar mandiri. 3. Penelitian yang akan datang diharapkan dapat memberikan waktu lebih lama untuk responden dalam mengisi kuesioner, di harapkan peneliti mengawasi responden saat mengisi kuesioner, serta bentuk tulisan dalam kuesioner saat di bagikan ke responden harus jelas dan spasi jangan

terlalu rapat-rapat dari satu kalimat ke kalimat lainnya,

\section{DAFTAR PUSTAKA}

Abraham, (2011). Exploring first-year undergraduate medical students' selfdirected learning readiness to physiology. Jurnal Advances in Physiology Education. VOL.35, hh. 393.

Akbar, (2015). Hubungan antara tingkat kecemasan dengan prestasi akademik mahasiswa di Fakultas Psikologi Universitas Muhammdiyah Surakarta. Naskah Publikasi Universitas Muhammdiyah Surakarta hal 8

Ambasari, (2016). Analisis Self Directed Learning Readiness terhadap Prestasi Belajar Mahasiswa Semester 2 Tahun Ajaran 2015/2016 Fakultas Kedokteran dan Ilmu Kesehatan Universitas Bengkulu. Jurnal Fakultas Kedokteran UNILA. Vol.1 no.2, hh. 263.
Anggraeni, N, (2013). Gambaran Tingkat Kecemasan Pada Mahasiswa Tingkat D-III Keperawatan Dalam menghadapi Uji Kompetensi di Universitas Pendidikan Indonesia. Universitas Pendidikan Indonesia: Bandung.

Bahkriansyah, (2012). Korelasi antara lama Studi dan Tingkat Kecemasan Mahasiswa. Jurnal Pendidikan Kedokteran Indonesia. Vol.1 no.2, hh. 55-56.

Conradie. P.W, (2014). Supporting SelfDirected Learning by Connectivism and Personal Learning Environments. International Journal of Information and Education Technology, Vol. 4, No. 3,hh. 254-255.

Dahlan, M.S (2014). Statistik untuk Kedokteran dan Kesehatan: Deskriptif, Bivariat, dan Multivariat, dilengkapi Aplikasi Menggunakan SPSS, EpidemiologiIndonesia: Jakarta.

Daniel, (2013). Hubungan Kecemasan dan hasil UAS-1 Mahasiswa Baru Fakultas Kedokteran Fakultas Sam Ratulangi Manado tahun ajaran 2012/2013. Jurnal Psikiatri Fakultas Kedokteran Universitas Sam Ratulangi. hh.4

Depkes. RI. (2013). Masalah kesehatan jiwa di Indonesia. Jakarta. Diakses (6 Desember 2017) pada http://www.depkes.go.id/article/view/ $2 \quad 01410270011 /$ stop-stigmadandiskriminasi-terhadap-orangdengangangguan-jiwa-odgj.htm/

Emjifari,A. (2012). Hubungan Antara Kemampuan Penyesuaian Diri Dengan Tingkat Kecemasan Ibu Dalam Menghadapi Masa Menopause. Skripsi(tidak diterbitkan). Surabaya : Program Studi Psikologi Fakultas 
Dakwah Institute Agama Islam Negeri Sunan Ampel.

Hashmat, (2008). Factors causing exam anxiety in medical students. Jurnal $\mathrm{J}$ Pak Med Assoc. Vol. 58, No. 4. Hh. 168-169

Hasianna (2014). Gambaran tingkat kecemasan pada semester satu di fakltas kedokteran universitas kristen maranatha tahun 2014. Jurnal universitas kedokteran kristen maranatha.

Hawari, (2011). Manajemen stres cemas dan depresi. Ed 1. Balai penerbitan Fakultas Universitas Indonesia : Jakarta.

Indah. (2017). Hubungan Gelombang Ujian dengan Tingkat Kecemasan dan Nilai Ujian Akhir Blok Dermatomusculskeletal Angatan 2014 Skripsi (tidak diterbitkan). Bandar Lampung : Fakultas Kedokteran Universitas Lampung

Karatas H, Alci B, Aydin H. (2013). Correlation among high school senior students test anxiety, academic performance and points of university entrance exam. Academic Journal. 8(13):919-926.

KKI, (2012). Konsil Kedokteran Indonesia

Kristiyani, (2008). Efektivitas metode Problem based Learning pada mata kuliah psikologi kepribadian 1 (replikasi). Jurnal Cakrawala Pendidikan. No.3.

Kusuma (2016). Hubungan Self Directed Learning Readiness (SDLR) Dengan Stress Pada Mahasiswa Kedokteran Umum Angkatan 2016. Skripsi (Tidak diterbitkan). Bandar Lampung:
Fakultas Kedokteran Universitas Malahayati

Mahardika, (2017). Hubungan Kesiapan belajar Mandiri dengan Performa Mahasiswa Fk Unila Angkatan 2015 dalam Mengikuti Tutorial Blok Spesial Sense. Skripsi (tidak diterbitkan). Bandar Lampung : Fakultas Kedokteran Universitas Lampung

Manu, (2017). Hubungan Kesiapan Mengajar Dan Tingkat Kecemasan Mahasiswa Praktek Microteaching Prodi Biologi Universitas Kristen Artha Wacana. Jurnal seminar nasional pendidikan sains II UKSW.

Maulana H \& Marcellina S. (2014). Perbedaan Kecemasan cedera berulang berdasarkan strategi coping stres pada atlet yang pernah cedera. Jurnal Penelitian dan Pengukuran Psikologi vol.3 no.1, hh. 9.

MEU. (2017). Rekap data mahasiswa angkatan 2017 program studi kedokteran umum UNMAL. Bandar Lampung

Morgan. Clifford T.King. R.A Weizz. JR. Schopler. J. (2008). Introduction of psychology. ( ed). Singapore : Mc Graw Hill Biik Company.

Monroe, (2016). The relationship between assessment methods and self-directed learning readiness in medical education. International Journal of Medical Education. 2016;7:75-80

Mu'arifah A. (2005). Hubungan Kecemasan dan Agresivitas. Jurnal Humanitas : Indonesian Psychological Journal vol.2 no.2, hh. 105.

Nyambe, (2015). Faktor-faktor yang mempengaruhi self-directed learning readiness pada Mahasiswa tahun 
pertama kedua dan ketiga di Fakultas Kedokteran Universitas Hasannudin dalam PBL. Jurnal Pendidikan Kedokteran Indonesia. Vol. 5. No. 2. Hh. 68-69

Niswiati, (2012). Kecemasan terhadap ketidakwajaran skor. Jurnal Evaluasi Pendidikan Vol. 3, No.1, Maret 2012, 61-63

Okta K, (2015). Penerapan Model Pembelajaran Mandiri Untuk Meningkatkan Minat dan Kemandirian Belajar Siswa Pada Mata Pelajaran Teknologi Informasi dan Komunikasi. Artikel IImiah Universitas Kristen Satya Wacana. Salatiga.

Pamungkasari EP. Probandari A. (2012) Pengukuran kemampuan belajar mandiri pada mahasiswa pendidikan profesi dokter. Skrpsi. Universitas Diponegoro semarang

Rahayu, (2013). Hubungan kepercayaan diri dan dukungan sosial dengan kecemasan mahasiswa menghadapi ujian OSCA. Skripsi. Fakultas Psikologi Universitas Muhammadiyah Surakarta.

Riga (2016). Hubungan Kecerdasan Emosi dengan Tingkat Kecemasan pada Remaja Menghadapi Ujian Semester Di SMA Negeri 2 Bandar Lampung tahun 2016. Skripsi. FK-UNMAL, Bandar Lampung.

Risma G.B. (2014). Korelasi kecemasan menghadapi ujian dengan hasil belajar mahasiswa yang mengikuti blok endocrine, metabolism and nutrition (EMN)Di Fakultas Kedokteran Universitas Lampung. Skripsi. Universitas Lampung.

Rusman
pembelajaran: $\quad \begin{gathered}\text { Model-model } \\ \text { mengembangkan }\end{gathered}$ profesionalisme guru. Edisi 2. Cetak ke-5. Jakarta: Rajawali pers.

Sandjaja. (2017). Hubungan antara tingkat kecemasan dengan tingkat sugestibilitas pada mahasiswa fakultas kedokteran tahun pertama. Jurnal kedokteran diponegoro. Vol. 6, No. 2, 241-242

Sadock, B.J. \& Virginia A.S, (2010). Kaplan \& Sadock Buku Ajar Psikiatri Klinis. Ed 2. Penerbit Buku Kedokteran EGC: Jakarta.

Sansgiry SS, Bhosle M, Sail K, (2006). Factors That Affect Academic Performance Among Pharmacy Students. American Journal of Pharmaceutical Education 2006; 70 (5) Article 104, hh. 1-2.

Sastroasmoro, (2014). Dasar-dasar metodologi penelitian klinis. Ed.5. jakarta: Sagung Seto.

Shadiqin (2016). Hubungan Motivasi Belajar Dengan Tingkat Self-Directed Learning Readiness (SDLR) Padamahasiswa Pendidikan Sarjanakedokteran Angakatn 2013 Di Universitas Malahayati. Skripsi. FKUNMAL, Bandar Lampung.

Shaikh, (2013). Comparison of readiness for self-directed learning in students experiencing two different curricula in one medical school. Jurnal gulf medical journal. 2013:2(1). hh.27-31

Standar pendidikan profesi dokter. Konsil kedokteran indonesia (KKI). Jakarta.2012

Subhakti, I.S. (2017). Perbandingan Tingkat Kecemasan pada peserta OSCE dan CBT ujian kompetensi mahasiswa program Profesi Dokter (UKMPPD) di Fakultas Kedokteran 
Universitas Malahayati Batch I Februari 2017, Skripsi, FKM-UNIMAL, Bandar Lampung.

Sugianto, (2016). Tingkat Self Directed Learning Readiness (SDLR) Pada Mahasiswa Kedokteran. Jurnal Universitas Lampung, Vol.5, No.5

Sumbayak, (2017). Hubungan antara skor self-directed learning readiness (SDLR) dengan pendekatan belajar Mahasiswa tahun pertama Fakultas Kedokteran Universitas Lampung. Skripsi FK-UNILA. Bandar Lampung.

Surbakti, (2017). Hubungan motivasi belajar terhadap Self-Directed Learning Readiness mahasiwa Kedokteran Universitas Lampung. Skripsi. FKUNILA, Bandar Lampung.

Triastuti, (2013). Hubungan Self Directed Learning Readinnes dengan Tingkat Kecemasan Mahasiswa Tingkat pertama Tingkat Pertama Tahun 20102011 Fakultas Kedokteran Universitas Muhammdiyah Surakarta. FK-UMS. Di akses (4 Desember 2017) http://journals.ums.ac.id/index.php/bi o medika/article/view/273.

Wijayanto R. Tjiptasura S, Bertha. (2013). Penelitian gambaran kesiapan belajar mandiri mahasiswa semester tujuh kurikulum berbasis kompetensi fakultas kedokteran universitas pelita harapan untuk menghadapi kepaniteraan klinik. Fakultas kedokteran universitas pelita harapan. Jakarta.

Yanti, (2013). Hubungan antara kecemasan dalam belajar dengan motivasi belajar siswa. Jurnal Ilmiah Konseling, vol.2, no.1, hh 295-286
Ujian di Kalangan Mahasiswa. jurnal Fakultas Psikologi Universitas Sumatera Utara. Majalah Kedokteran Nusantara Volume 42 No. 1, hh. 4850.

Zulharman. 2008. Peran Self Directed learning Readiness (SDLR) pada Prestasi Belajar Mahasiswa Tahun Pertama Fakultas kedokteran Universitas Riau. Tesis. Yogyakarta: Universitas Gadjah Mada.

Zulkarnain, Novliadi, (2009). Sense of Humor dan Kecemasan Menghadap 